\title{
MODERN TRENDS IN ACUTE RHEUMATISM
}

BY

\author{
S. LEFF
}

(RECEIVED FOR PUBLICATION JUNE 13, 1955)

The last few years have witnessed a marked decline in the incidence of acute rheumatic infection in childhood, but it "is still a dangerous menace demanding the continued attention of paediatricians, public health officers, and laboratory workers" (Annotation, 1955). The serious nature of the disease was revealed in a follow-up of children in the United States: after 10 years approximately one in three had died, and after 20 years more than half (Ash, 1948); in general, a rheumatic child has but a fifty-fifty chance of surviving to the age of 40 years (Wilson and Lubschez, 1948). Rheumatic heart disease is probably responsible for the deaths of one in ten of all heart sufferers and for practically all the deaths from heart disease of persons below the age of 40 years; in the under 40 s it takes second place only to tuberculosis.

\section{Incidence and Trends}

It is difficult to estimate the incidence of rheumatism of childhood: perhaps no disease is so unpredictable-its appearance often varies in successive attacks, and the extent of damage to the heart is often unrelated to the severity of the attack. The acute form is easily recognized, but the insidious (sub-acute) form with vague growing pains and no obvious involvement of the joints may easily be missed; often the only sign that a child has suffered from rheumatism is the finding of a damaged heart. Nevertheless, it is possible to estimate the incidence of this disorder from a study of the mortality and attack-rates of acute rheumatic fever and of the numbers suffering from rheumatic heart disease.
Mortality.-The Registrar-General's returns of mortality from rheumatic fever and heart disease in persons under 15 years of age for England and Wales give some indication of the incidence of acute rheumatism (Table I). Until 1947 these returns were almost the only reliable sources of information.

Mortality declined steadily from 1938 to 1942 with a probable simultaneous fall in incidence (Glover, 1943; Gale, 1945). There was a sharp rise in mortality in 1943 followed by a fall to a new low point in 1946. In 1947 and again in 1948 slight rises occurred, followed by substantial decline in 1950 (17 per cent. for males and 20.7 per cent. for females); the preponderance of female over male deaths was less in 1950 than ever before. There was a further and greater substantial decline in 1951, when the mortality was just less than one-half of that in 1946, the first post-war year. Further reductions in the following years were greater for females, with the result that in 1953 the mortality for females was only very slightly higher than for males.

Incidence of Heart Damage.-In a disease with a low mortality it is impossible to judge accurately the incidence from the number of deaths alone. In a recent observation period of one year, there were only six deaths among 497 patients under the age of 16 (M.R.C. and A.H.A., 1955), but even a knowledge of the number of cases of rheumatic fever or acute rheumatism is not enough, because the main danger is from damaged hearts, which often develop after few or no symptoms as in the sub-acute forms. Another indication of the extent of this disorder can

TABLE I

DEATHS FROM RHEUMATIC FEVER (CLASSIFIED BY 6A REVISION, ENGLAND AND WALES)

\begin{tabular}{|c|c|c|c|c|c|c|c|c|c|c|c|c|c|c|}
\hline Year & 1940 & 1941 & 1942 & 1943 & 1944 & 1945 & 1946 & 1947 & 1948 & 1949 & 1950 & 1951 & 1952 & 1953 \\
\hline Males & 509 & 448 & 380 & 406 & 446 & 416 & 360 & 350 & 363 & 312 & 259 & 164 & 144 & 143 \\
\hline Females.. & 742 & 565 & 513 & 623 & 556 & 521 & 415 & 427 & 449 & 391 & 310 & 214 & 184 & 167 \\
\hline Total $\ldots$ & 1,251 & 1,013 & 893 & 1,029 & 1,002 & 937 & 775 & 777 & 812 & 703 & 569 & 378 & 328 & 310 \\
\hline
\end{tabular}


therefore be obtained from estimates of the number of damaged hearts caused by rheumatism.

In the United States, about 30,000 people under the age of 25 years develop rheumatic fever or chorea every year; and 600,000 under 50 years of age have rheumatic heart disease (Hill and others, 1949). The rejection from military service of four in ten young men with heart disease in San Francisco, and of seven in ten in Chicago, was due to rheumatic heart damage (Griffith, 1948).

Parkinson (1945) quoted Dr. Stocks's estimate that in Great Britain there were at least 300,000 persons of both sexes with heart disease, the majority rheumatic in origin. It appeared that this estimate was too high, but in a study of returns of mass-radiography over a period of 3 years the incidence of rheumatic heart disease was found to be 4 per 1,000 (Kerley, 1949), and was in fact probably higher, since the $x$ ray detected only considerable alterations in the shape or size of the heart. Parkinson urged that a central national committee should be set up to organize and extend existing special facilities, such as supervisory clinics and long-stay hospital schools, thus providing greater opportunities for much needed research into causation and prevention.

Early in 1946, at the request of the Minister of Health, the President of the Comitia of the Royal College of Physicians appointed a special committee "To consider the prevention and management of rheumatic heart disease". This committee recommended that acute rheumatism, including valvular disease of the heart, in school children up to 16 years of age should be made compulsorily notifiable. In October, 1947, this was put into operation in Bristol and Sheffield, and also in a mixed urban and rural area, where there were good facilities for the diagnosis and treatment of rheumatic fever. The results are shown in Table II. It was hoped that the relative incidence in the different areas would give some indication of the importance of genetic and social factors in the evolution of the disorder.

In 1948 the number of notifications already reflected the great decline in incidence compared with 20 years before. In the first year, after clinical examination and in some cases a period of observation, only just over 60 per cent. were accepted as suffering from acute rheumatism in an active stage; nearly 20 per cent. of notified cases had quiescent heart disease, and 10 per cent. heart disease of nonrheumatic origin. The incidence was thus less than 1 per 1,000 of the child population, and in some areas less than 0.5 per 1,000 . Similar evidence of a decline in incidence was suggested by using data from a children's supervisory rheumatism clinic at Walthamstow (Sheldon, 1948).

In 1950 , on the recommendation of the Rheumatic Fever Committee of the Royal College of Physicians, two more towns and one rural area were added for notifications, raising the number of the child population at risk from just over 300,000 to over 500,000 (Table II). The notification rate per 1,000 children per annum for 1950 was 0.45 compared with 0.35 in 1949 and 0.55 in $1948 ; 0.27$ per 1,000 had acute rheumatism with active rheumatic heart disease.

It is estimated that, if these figures were applied to the country as a whole, between 4,000 and 5,000 new cases of acute rheumatism occurred in children of school age every year; a review of the evidence indicated that the post-war attack-rates were only one-third or one-quarter as great as the pre-war figures (Conybeare, 1951). The decline has not been uniform; in 1951, the rate in some areas was less than one-half that in 1950 , but there was little change in the totals for $1952 / 53$, when there were increases in the two large towns and there were reductions in the rural areas.

Causes for the Decline in Incidence.-Knowledge

TABLE II

NOTIFICATION OF ACUTE RHEUMATISM

(1948-50, 4 TOWNS AND 2 COUNTIES; 1950-53, 6 TOWNS AND 3 COUNTIES)

\begin{tabular}{|c|c|c|c|c|c|c|}
\hline \multirow[b]{2}{*}{ Year } & \multirow{2}{*}{$\begin{array}{c}\text { Estimated Child } \\
\text { Population, } \\
\text { 0-14 yrs (approx.) }\end{array}$} & \multirow{2}{*}{$\begin{array}{l}\text { Total } \\
\text { Notified } \\
\text { Cases }\end{array}$} & \multicolumn{4}{|c|}{ Classification of Notified Cases } \\
\hline & & & Acute Rheumatism & $\begin{array}{c}\text { Chronic Rheumatic } \\
\text { Heart Disease }\end{array}$ & No Rheumatism & Not Classified \\
\hline 1948 & 309,000 & 271 & 170 & 48 & 39 & 14 \\
\hline 1949 & 313,000 & 134 & 110 & 3 & 20 & 1 \\
\hline 1950 & 319,000 & 173 & 141 & 4 & 20 & 8 \\
\hline 1951 & 510,000 & 162 & 130 & 8 & 23 & 1 \\
\hline 1952 & 510,000 & 161 & 133 & 6 & 22 & - \\
\hline 1953 & 510,000 & 184 & 149 & 1 & 31 & 3 \\
\hline
\end{tabular}


of the causes of this decline in incidence can help to guide future policy in prevention and treatment. Three main causes have been suggested: a change in the relationship between man and the haemolytic streptococcus, better methods and facilities for prevention and treatment, and improvements in the social environment with the decline in the general extent of poverty.

(1) Haemolytic Streptococcus and Acute Rheumatism.There is strong evidence of the association of the haemolytic streptococcus with acute rheumatism. A haemolytic streptococcus infection often precedes the attack by 2 to 4 weeks, and it has been estimated that rheumatic sequelae complicate 1-2 per cent. of streptococcal upper respiratory infections (Leader, 1953). Several epidemics of streptococcal pharyngitis and scarlet fever occurred during World War II, followed by a high incidence of rheumatic fever or relapses, and a study of the sickness records of the R.A.F. showed that morbidity from rheumatic fever and scarlet fever were closely related in young adults (Macdonald, 1950). Except for the year 1942 the rise and fall of the figures for deaths from rheumatic fever have been paralleled by the number of notified cases of scarlet fever.

Rheumatic subjects have a much higher carrier rate of Group A streptococci in their throats (50.5 per cent. as compared with 12.5 per cent. of normal), and there is often a reappearance or an increase in the numbers of haemolytic streptococci in the throats of individual cases of rheumatic fever which relapse. Haemolytic streptococci have been grown from rheumatic fever necropsies from the tonsils, cervical and mediastinal glands, and heart valves (Collis, 1931; Green, 1939, 1942).

Rheumatic subjects display a considerably higher skin sensitivity to streptococcal extracts (endotoxins) than normal subjects, and it is possible to measure the antibody titre for streptococcal haemolysin in human serum (Todd and others, 1939). This reaction is specific to the streptococcus and is not an expression of the rheumatic individual's general hyperactivity of an immune response (Miller and others, 1953; Kuhns and McCarty, 1954). About 80 per cent. of rheumatic fever cases show a rise of streptolysin -O titre which reaches its maximum in 3 to 4 weeks (Mote and Jones, 1941; Green, 1941).

It has been suggested that the decline in the incidence of rheumatic fever and in the mortality from scarlet fever is due either to the fact that man is more immune, or to the fact that the streptococcus is less virulent (Glover, 1946).

It must be remembered that, although streptococcal infection is commonly associated with rheumatic fever, it is not an exclusive factor, and in one series it accompanied only thirteen out of 42 cases; the rheumatic fever followed many varied infections of Eastern desert life, such as malaria, dysentery, and sandfly fever (Copeman, 1944).

(2) Prevention and Treatment.-Chemoprophylaxis is now used in an effort to avoid rheumatic fever sequelae by streptococcal infections during the acute phase, both in the primary attack and in relapses, and by sterilizing the upper respiratory passages of carriers.

Sulphonamides were first used but resistant strains appeared and toxic symptoms occasionally developed. Oral penicillin, 200,000 units three times daily on an empty stomach was then given as a prophylactic (Bywaters, 1954), but it had to be given for a long period, and it did not seem to affect rheumatic fever recurrences, although it markedly reduced the number of occasions streptococci were isolated from the throat (Gale and others, 1952). The Chief Medical Officer of the Ministry of Health (1953) commented on its use as follows:

It seems, in fact, unlikely that the more or less continuous oral administration of penicillin is a really practicable means of preventing rheumatic heart disease.

More recently, better results appear to have been given by intramuscular injection of long-acting penicillins (Benzethacil or Bicillin, N, $\mathbf{N}^{1}$-dibenzykethylenediamine dipenicillin G) monthly with no significant toxicity (Diehl and others, 1954; Stollerman and Rusoff, 1952). Group A streptococci were eliminated from the throats of carriers and new infections were almost completely prevented (Perry and Gillespie, 1954). Aureomycin has also been used with good results in a small group of cases (McVay and Sprunt, 1953).

Recently, the American Heart Association's committee published its recommendations on the prevention of rheumatic fever (American Heart Association, 1953). For treating streptococcal infections, intramuscular procaine penicillin is suggested, given early and continued until the organisms are eradicated from the throat (Wannamaker and others, 1951). For preventing streptococcal infections, sulphadiazine is suggested because of its relative low cost in prolonged administration; the risk of developing resistant organisms is much less in the rheumatic patient treated at home compared with the mass prophylaxis in closed communities under Service conditions (Finland, 1951).

Chemoprophylaxis is clearly a very big undertaking; it should include all those under the age of 18 who have had rheumatic fever or chorea, and also all those over 18 who have had an attack within 5 years (Bland and Jones, 1951), and as it could not control large reservoirs of infection (Kohn and others, 1953), either larger doses would have to be given or the tonsils of all those at risk would have to be examined periodically. Even if the evidence for the efficacy of chemoprophylaxis were much stronger, the problems of the prevention of the first attack of rheumatic fever and of the mild symptomless case would still have to be faced.

Chemoprophylaxis has been in use for too short a period to have played a significant part in the decline in incidence.

Nor has treatment taken an important role in the decline in incidence. When cortisone was introduced, it was thought that a powerful new weapon had been found in the struggle against acute rheumatism. But the results proved disappointing. Many reports revealed that while cortisone and ACTH had a suppressive action, they had little effect in preventing the progress of valvular 
and heart disease (Kuttner and others, 1952; Sheinkoff and others, 1952). Better results were obtained by giving cortisone early before overt clinical damage had occurred (Wilson, 1953), and ACTH given by continuous intravenous drip, while not improving results, cut down drug costs to only one-tenth of that required in intramuscular therapy (Griffith and others, 1952).

Controlled experiments have revealed that there is very little to choose between salicylates and cortisone (Illingworth and others, 1954). Recently, three randomly controlled groups covering 497 patients (240 in Great Britain and 257 in the United States) were treated with $\mathrm{ACTH}$, cortisone, and aspirin, and at the end of one year there was no significant difference between the three groups in the status of the heart (M.R.C. and A.H.A., 1955); none of the three drugs produced uniform termination of the disease, and with each of them some patients developed fresh manifestations during treatment. The hormones controlled certain acute manifestations more promptly, but the symptoms had a greater tendency to reappear for a limited period after cessation of treatment. The results of treatment were measured against such separate manifestations as temperature, pulse-rate during sleep, erythrocyte sedimentation rate, joint involvement, chorea, erythema marginatum, nodules, and the status of the heart-its size, atrioventricular conduction time, murmurs, congestive failure, and pericarditis.

A survey over a longer period may show that the hormone-treated group has an advantage, but this seems unlikely to be spectacular. It has even been suggested that the action of salicylates and cortisone is similar (Leader, 1951a; Annotation, 1955), though it seems improbable that the salicylates produce their action by increasing adrenocortical activity.

Other drugs such as Butazolidin have met with no greater success (Fleming and Will, 1953), and although better results might be obtained by combining Butazolidin with penicillin, caution must be exercised because of the risk of liver damage (Hockerts, 1953).

(3) Social Measures.-A good rheumatism scheme can play an important part in reducing the incidence of rheumatic fever and its relapses. Such a scheme should include proper centres for educating the public, detecting cases early, and supervising patients when they come out of hospital, by arranging for additional foods and clothing, special holiday facilities, and rehousing. For damaged hearts special facilities should be provided, such as prolonged rest in hospital schools together with continuation of treatment and schooling in special day and convalescent schools.

There has been no marked expansion in the services in the past few years to conform to such a scheme. In 1947 a special unit of 100 beds for the study and care of juvenile rheumatism was attached to the Canadian Red Cross Memorial Hospital, Taplow, with a plan to expand to 200 beds. Other centres have been established at London, Sheffield, Newcastle, and Cardiff, but they cannot yet have played a significant role in the general decline of rheumatic fever in the country as a whole.

Family studies (Gray and others, 1952; Stevenson and
Cheeseman, 1953), including pedigrees of rheumatic families (Pickles, 1943; Beers, 1949), and records of identical and non-identical twins (Kaufmann and Scheerer, 1938; Perry, 1940), have suggested that heredity is involved, and a recent long-term study appears to have confirmed this (Wilson and Schweitzer, 1954), but no study has been able to overcome completely the usual difficulties of using diagnoses universally accepted, of unreliable histories, and of selecting families for the controls equivalent to those which have a rheumatic subject.

Other studies, however, have been even less definite. One confirmed the well-known relative immunity of blue-eyed children based on some genetic factor, but found no evidence that some families are more prone to develop rheumatic fever than others (Hewitt and Stewart, 1952). Another suggested that the mode of transmission of susceptibility is best left an open question; no significant difference was found between the families with an affected parent and those with normal parents (Uchida, 1953). Another suggested that the incomplete manifestation of the disease makes it difficult to determine the exact mode of inheritance, although it is possible to exclude both the hypothesis of a single autosomal completely dominant gene and that of complete sexlinkage (Stevenson and Cheeseman, 1953).

Even where heredity is considered to play a part, it is admitted that the more important factors are probably exposure to streptococcal infection and conditions of poverty. In any case the recent decline in the incidence of rheumatic fever could not possibly have been due to changes in genetic factors, because insufficient time has elapsed for them to have developed.

Many workers have emphasized the significance of social conditions in the evolution of rheumatic fever (Ryle, 1946; Perry, 1944), but recently with the decline in incidence there has been a tendency to minimize their importance, because the social differences are no longer so marked (Leader, 1951b). It has recently been suggested that there is no evidence that acute rheumatism is associated either with bad housing conditions or with poverty per se, and that the size of the household and the ages of the children included in it are more important (Hewitt and Stewart, 1952).

Before the war the rheumatic heart death rate was strongly associated with industrial and town life, and, above all, with poverty (Morris and Titmuss, 1942). Fig. 1 (opposite) illustrates the mortality rates in children of school age (5-15 yrs) in county boroughs, urban districts, and rural districts, in England and Wales, compared with those in the comparatively rural and wellto-do S.W. England and the predominantly industrial and poverty-stricken S. Wales in the years 1929-33.

It was perhaps even more sensitive to social conditions than infant mortality or the phthisis death rate in young women, and it responded to even short changes in such conditions, as measured by the level of unemployment (Morris and Titmuss, 1944).

A study of the county boroughs of England and Wales classified in ten groups (A to J) according to their experience of unemployment between 1927 and 1938 showed 

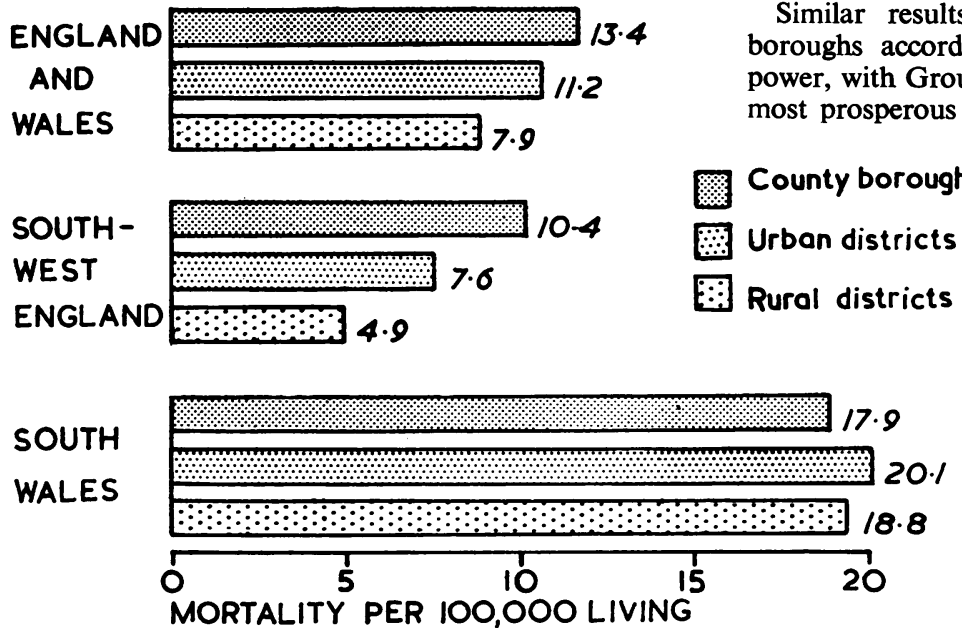

Fig. 1.-Mortality from heart disease per 100,000 living, in children aged 5 to 15 yrs, both sexes combined, in England and Wales, S.W. England, and S. Wales, by county boroughs, urban districts, and rural districts, in 1929-33.

a marked difference in mortality from rheumatic heart disease in Group A (towns which suffered most unemployment) and in Group J (towns with least unemployment). Although there has been a closing of the gap between these two groups as a result of the post-war improvement in social conditions and the decline in mortality, a marked difference still exists (Fig. 2).
Similar results are obtained by grouping county boroughs according to income levels and purchasing power, with Group 1 as the poorest and Group 4 as the most prosperous in 1949-50 (Fig. 3).

Even in discussing other factors County boroughs in the causation of the decline in incidence, due regard has to be given to such changes in the social environment such as the decrease in poverty caused by abundant employment during wartime, the greatly increased provision of milk for all children and of solid meals for school children, the more balanced diet for everyone due to rationing and the national flour and bread, and the long "changes of air" due to evacuation which at the most susceptible ages tended to decrease the effect of urbanization (Glover, 1946). A recent study links the role of the streptococcus with that of the social environment by demonstrating that the carrier rate of the streptococcus varies with the rate of tonsillectomy, the amount of the rental, and the incidence of rheumatic fever (Holmes and Rubbo, 1953).

Clearly, of all the factors responsible for the decline in the incidence of acute rheumatism in childhood, the improvement in the social conditions
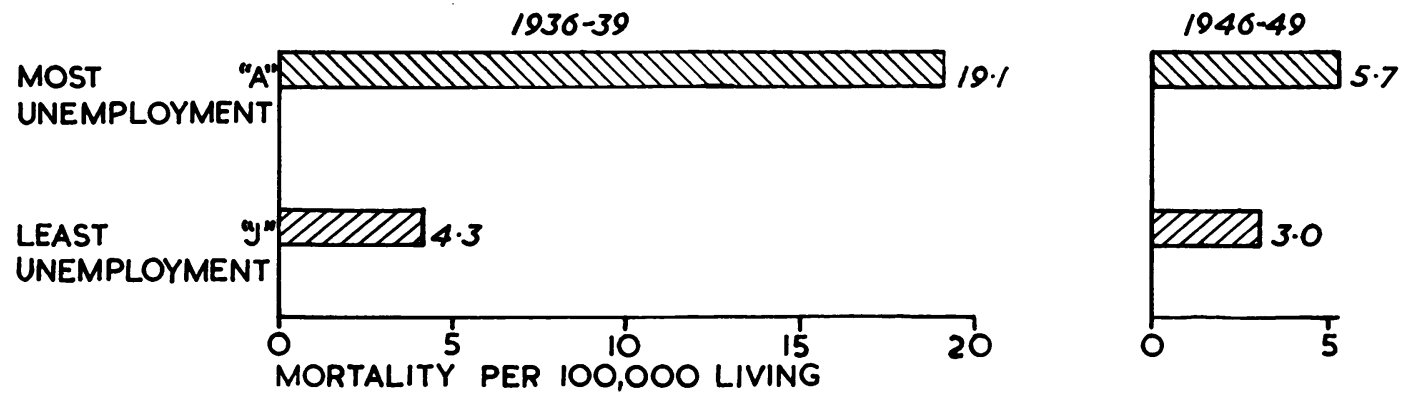

Fig. 2.-Mortality from heart disease per 100,000 living, in children aged 5 to 15 yrs, both sexes combined, in areas of least unemployment in S. Wales (J) and most unemployment in England and Wales (A), comparing the periods 1936-39, and 1946-49.

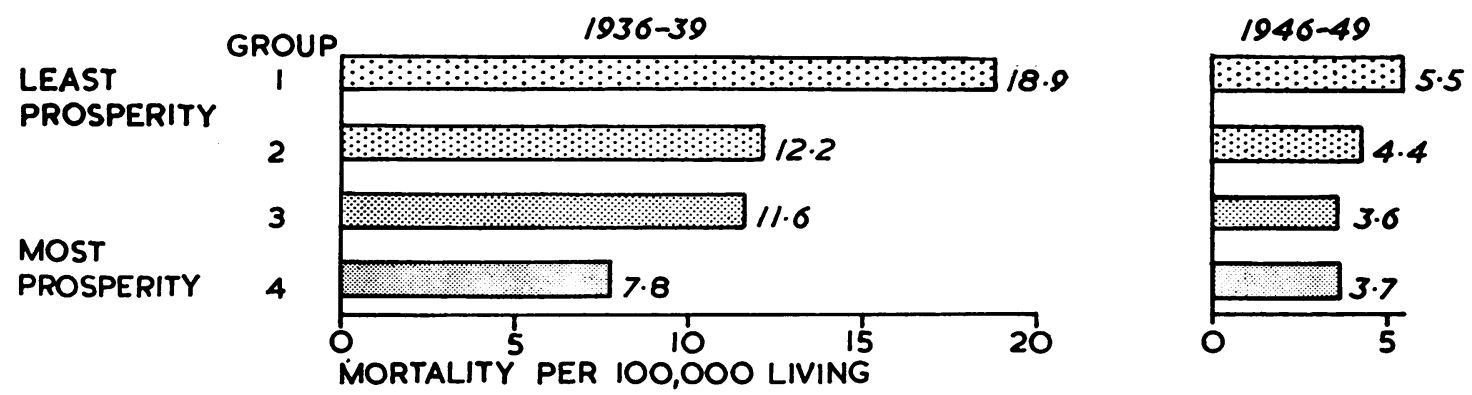

Fig. 3.-Mortality from heart disease per 100,000 living, in children aged 5 to 15 yrs, both sexes combined, in county boroughs of four grades of prosperity (1-4), comparing the periods 1936-39, and 1946-49. 
stands out as the most important. This finding serves as a guide for the future in the struggle against this disorder. For example, Fig. 3 shows that where the purchasing power and income levels are highest, the mortality from rheumatic heart disease is reduced by about 50 per cent. Essentials in improved social conditions are better housing, meals at school, protective clothing, and adequate convalescent and rest-home facilities. In addition, better facilities for prevention and treatment will play an important part.

\section{Summary}

Deaths from rheumatic fever in England and Wales declined from 1,251 in 1940 to 310 in 1953; annual post-war figures, estimated at between 4,000 and 5,000 new cases in school children, were between a third and a quarter of pre-war figures.

Streptococcal infection is commonly associated with rheumatic fever, but is not an exclusive factor. Good results have been obtained by some methods of chemoprophylaxis, but these have been in use for too short a period to have been a significant factor. Treatment with cortisone and Butazolidin has proved disappointing. There has been no large-scale expansion of special rheumatism centres.

Heredity may play a part, but insufficient time has elapsed for changes in genetic factors to be a significant cause. More important factors are exposure to streptococcal infections and conditions of poverty. The importance of environment is shown in studies of the incidence of the disease in towns grouped according to income levels and purchasing power, which still show marked differences, despite a general decline in mortality.

\section{REFERENCES}

American Heart Association (1953). Lancet, 1, 285.

Annotation (1955). Brit. med. J., i, 589.

Ash, R. (1948). Amer. J. Dis. Child., 76, 46.

Beers, C. V. (1949). Hereditas (Lund), Suppl. vol.: "Proc. 8 int Congr. Genetics, 1948", p. 534.

Bland, E. F., and Jones, T. D. (1951). Circulation, 4, 836.

Bywaters, E. G. L. (1954). Courrier (Paris), 4, 357.

Collis, W. R. F. (1931). Lancet, 1, 1341.

Collis, W. R. F. (1931). Lancet, 1, 1341.

Copeman, W. S. C. (1944). Annals of the Rheumatic Diseases, 4, 11.

Diehl, A. M., Hamilton, T. R., Keeling, I. C., and May, J. S. (1954). J. Amer. med. Ass., $155,1466$.

Finland, M. (1951). Bull. N.Y. Acad. Med., 27, 199. Fleming, J., and Will, G. (1953). Annals of the Rheumatic Diseases,

Gale, A. H. (1945). Arch. Dis. Childh., 20, 2.

Gillespie, W. A., and Perry, C. B. (1952). Lancet, 2, 61.

Glover, J. A. (1943). Lancet, 2, 51.

- (1946). Monthly Bull. Minist. Hlth (Lond.), 5, 222.

Gray, F. G., Quinn, R. W., and Quinn, J. P. (1952). Amer. J. Med., $13,400$.

Green, C. A. (1939). Annals of the Rheumatic Diseases, 1, 86.

(1941). J. Path. Bact., 53, 223.

- (1942). Annals of the Rheumatic Diseases, 3, 4

Griffith, G. C. (1948). Amer. J. Publ. Hlth, 38, 682.

- and others (1952).

Hewitt, D., and Stewart, A. (1952). Brit. J. soc. Med., 6, 161.
Hill, L. F., Hubbard, J. P., Harris, T. N., Jackson, R. L., and Wheatley, G. M. (1949). Pediatrics (Panel Discussion on Rheumatic Fever), 3, 680.

Hockerts, T. (1953). Disch. med. Wschr., 78, 669.

Holmes, M. C., and Rubbo, S. D. (1953). J. Hyg., 51, 450.

Illingworth, R. S., Burke, J., Doxiadis, S. A., Lorber, J., Philpott M. G., and Stone, D. G. H. (1954). Quart. J. Med., 23, 177. Kaufmann, O., and Scheerer, E. (1938). Z. mensch. Venerb. KonstLehre, 21, 687.

Kerley, P. (1949). Proc. roy. Soc. Med., 42, 1042

Kohn, K. H., Milzer, A., and MacLean, H. (1953). J. Amer. med. Ass., 151, 347 .

Kuhns, W.'J., and McCarty, M. (1954). J. clin. Invest., 33, 759.

Kuttner, A. G., Baldwin, J. S., McEwen, C., Bunim, J. J., Ziff, M., and Ford, D. K. (1952). J. Amer. med. Ass., 148, 628.

Leader (1951a). Lancet, 1, 780.

- (1951b). Brit. med. J., 2, 162.

- (1953). Ibid., 1, 278.

Macdonald, T. C. (1950). Ibid., 1, 992.

McVay, L. V., Jr., and Sprunt, D. H. (1953). New Engl. J. Med. 249. 387 . J.

Medical Research Council and American Heart Association (1955). Brit. med. J., 1, 555 .

Miller, J. M., Kibrick, S., and Massell, B. F. (1953). J. clin. Invest. 32,691 .

Ministry of Health (1953). "Annual Report of the Chief Medical Officer, 1951", Pt. III, p. 97.

Morris, J. N., and Titmuss, R. M. (1942). Lancet, 2, 59.

,, (1944). Med. Offr., 72, 69, 77, 85.

Mote, J. R., and Jones, T. D. (1941). J. Immunol., 41, 35.

Parkinson, J. (1942). Lancet, 2, 657.

Perry, C. B. (1940). Arch. Dis. Childh., 15, 177.

(1944). Bristol med.-chir. J., 61, 1.

and Gillespie, W. A. (1954). Brit. med. J., 2, 729.

Pickles, W. N. (1943). Lancet, 2, 241.

Ryle, J. A. (1946). J. roy. San. Inst., 66, 277.

Sheinkopf, J. A., Griffith, G. C., Morrison, R., and Starr, P. (1952). Amer. J. med. Sci., 224, 390.

Sheldon, W. (1948). Acta paediat. (Uppsala), 36, 383.

Stevenson, A. C., and Cheeseman, E. A. (1953). Ann. Eugen. (Lond.), 17, 177.

Stollerman, G. H., and Rusoff, J. H. (1952). J. Amer. med. Ass., 150,1571

Todd, E. W., Coburn, A. F., and Hill, A. B. (1939). Lancet, 2, 1213.

Uchida, I. A. (1953). Amer. J. hum. Genet., 5, 61 .

Wannamaker, L. W., Rammelkamp, C. H., Denny, F. W., Brink, W. R., Houser, H. B., and Hahn, E. D. (1951). Amer. J. Med., 10, 673 .

Wilson, M. G. Helper, H. N., Lubschez, R. Hain, K., and Epstein, N (1953). Amer. J. Dis. Child., 86, 131 .

- and Lubschez, R. (1948). J. Amer. med. Ass., 138, 794

, and Schweitzer, M. (1954). Circulation, 10, 699.

\section{Tendences actuelles du rhumatisme aigu}

\section{RÉSUMÉ}

Le nombre des décès de rhumatisme articulaire aigu en Angleterre et au pays de Galles a baissé de 1,251 en 1940 à 310 en 1953; les chiffres annuels d'après-guerre, estimés entre 4,000 et 5,000 cas nouveaux parmi les enfants d'âge scolaire, n'étaient qu'un tiers ou un quart de ceux d'avant-guerre.

L'infection streptococcique se trouve habituellement associée au rhumatisme articulaire aigu, mais elle n'y est un facteur exclusif. On a obtenu de bons résultats avec quelques méthodes de chimio-prophylaxie, mais leur emploi n'a pas été assez prolongé pour qu'on puisse les considérer comme un facteur significatif. Le traitement par la cortisone et par la Butazolidine s'est avéré décevant. Il n'y a pas eu d'expansion sur une grande échelle de centre spéciaux pour le rhumatisme.

L'hérédité peut jouer un rôle, mais les facteurs génétiques n'ont pas eu assez de temps pour acquérir de limportance. Parmi les facteurs plus importants on trouve l'exposition à l'infection streptococcique et la pauvreté. L'importance du milieu est mise en évidence par l'étude de la fréquence du rhumatisme articulaire aigu dans les villes groupées selon le revenu et le pouvoir d'achat des habitants; on y observe encore de grandes différences malgré la baisse générale de la mortalité. 
Tendencias actuales del reumatismo poliarticular agudo

\section{Sumario}

El número de muertes de reumatismo poliarticular agudo en Inglaterra y en el país de Gales bajó de $1 \cdot 251$ en 1940 a 310 en 1953; las cifras anuales después de la guerra, estimados entre 4.000 y 5.000 casos nuevos entre niños de escuela, representan tan sólo una tercera o una cuarta parte de las de antes de la guerra.

La infección estreptocóccica se ve generalmente asociada con el reumatismo poliarticular agudo pero no constituye un factor exclusivo. Se lograron buenos resultados con algunos métodos de quimioprofilaxis, pero éstos no fueron empleados durante un tiempo suficiente para constituirse en un factor significativo. El tratamiento con cortisona y con Butazolidina fué delusivo. No hubo expansión en gran escala de centros especiales para el reumatismo.

La herencia puede desempeñar un papel, pero los factores genéticos no tuvieron tiempo suficiente para alcanzar importancia. Entre los factores más importantes se destacan la exposición a la infección estreptocóccica y la pobreza. La importancia del medio se ve revelada por los estudios de la incidencia del reumatismo poliarticular agudo en ciudades agrupadas según los ingresos y el poder de compra, donde se observan todavía grandes diferencias a pesar de la baja general de la mortalidad. 